\title{
Te Mana Te Kawanatanga: The Politics of Maori Self-Determination.
}

Reviewed by Giselle Byrnes

Te Mana Te Kawanatanga: The Politics of Maori Self-Determination. Mason Durie.

Auckland: Oxford University Press, 1998.

In 1983 the Waitangi Tribunal released its Motunui-Waitara Report, which described the Treaty of Waitangi, signed between New Zealand Maori and the Crown in 1840, as a 'developing social contract'. Since this finding, a number of books have considered the Treaty of Waitangi not simply as an historical relic, but as a covenant which needs to be continually revisited in the light of present social and economic imperatives. I. H. Kawharu's edited collection of essays, Waitangi: Maori and Pakeha Perspectives of the Treaty of Waitangi (1989), Paul McHugh's The Maori Magna Carta: New Zealand Law and the Treaty of Waitangi (1991), and Andrew Sharp's recently revised Justice and the Maori: The Philosophy and Practice of Maori Claims in New Zealand since the 1970s (1997), all from Oxford University Press, are perhaps the most notable of these critiques. Mason Durie's latest offering, Te Mana Te Kawanatanga: The Politics of Maori Self-Determination, is a welcome addition to an emerging body of criticism that presents a particularly Maori perspective on current issues facing Maori.

The book, as Durie points out, is not a history of Maori relationships with the state; rather, it is an examination of certain issues that, over the past decade, have fashioned the attitudes of both Maori and the Crown as Maori have struggled to assert a greater degree of cultural, economic and political autonomy in Aotearoa/New Zealand. Te Mana Te Kawanatanga is essentially an analysis of Maori aspirations, discussed with reference to their distinct cultural identity, and set against the challenges presented by a changing New Zealand national identity. The book also needs to be considered in the broader international context, where it has only recently been recognised that indigenous peoples should exercise rights of self-determination.

Te Mana Te Kawanatanga addresses two major themes: autonomy and self-determination, and Maori interaction with the state and the responses of the state to Maori initiatives. The twin focus of the book is reflected in the Maori and English titles, which-it must be noted-are not intended as a literal translation of each other, but stand in contrast to mirror the often difficult history of the Maori-Crown relationship. While the Maori title comprises the 
two Maori words that have, since the signing of the Treaty in 1840, come to signify Maori efforts to achieve self-determination, the English title implies that after the signing of the Treaty, Maori aspirations for autonomy were no longer guaranteed. The two titles, therefore, reflect the complexity surrounding the practical implications of Maori sovereignty and self-determination, issues that have been-and that remain-important ones for all New Zealanders.

The theme of the connection between Maori autonomy and the power of the state is reiterated throughout the book. Durie does not assume a concensus among his readers. In the first chapters he questions what selfdetermination actually means and how it might be identified and assessed. He concludes with a thoughtful suggestion that the aims of selfdetermination-as discussed with reference to the history and experience of Maori-extend beyond the realms of academic postcolonial discourse to touch all Maori people now and in the future. This argument no doubt has a great deal of significance for indigenous people everywhere.

The two central themes are reinforced by the structure of the book; it sets up a two-dimensional paradigm that integrates 'the foundations of Maori control and authority, nga pou mana' with those factors 'relevant to Maori realisation of self-determination, te mana whakahaere' (p. 13). In other words, each chapter considers a particular aspect of Maori society in relation to the points of collusion and difference in the Maori-Crown compact. They range across a discussion of the environment, identity and heritage, Maori participation in the political process, land legislation, fishing, and issues of autonomy and governance. One chapter is entirely devoted to the Treaty of Waitangi, once again emphasising the significance of the Treaty in contemporary New Zealand, and specifically in the context of current Treaty claims negotiations and settlements. It is in relation to this that Durie raises one of the most provocative arguments in the book, and one that expands on the 'developing social contract' thesis. He suggests that while Maori (and by implication, the Crown) need a clear Treaty policy with which to negotiate settlements that take account of past injustices as well as provide for future needs, we should perhaps not be too ready to see the Treaty as the universal panacea for all Maori social and economic ills.

Te Mana Te Kawanatanga is a timely publication by a respected Maori commentator on contemporary Maori and Treaty issues. The narrative has a logical, almost formulaic, style which is complemented by the presentation of a wealth of statistical data presented in tabular format throughout the text. The study will find a ready audience not only among students, but also among policy makers and others (particularly those who might question the utility of the Treaty) seeking a trenchant analysis of issues currently affecting Maori. Moreover, Te Mana Te Kawanatanga will be of real interest to readers beyond 
New Zealand shores in the wider Asia-Pacific region who are thinking through issues of self-determination and cultural autonomy and about how these issues might be identified and articulated. On Mason Durie's evidence, New Zealand Maori may well be leading the way in this respect.

Giselle Byrnes

Wellington 